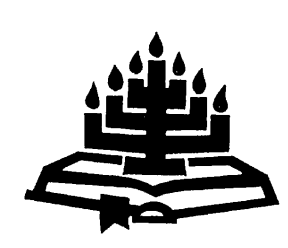

\title{
The year of jubilee: a hermeneutic for social and moral transformation in South Africa
}

\author{
S. Barry \\ School of Ecclesiastical Science \\ Potchefstroom Campus \\ North-West University \\ POTCHEFSTROOM \\ E-mail: 3rmethodist@lantic.net
}

\begin{abstract}
The year of jubilee: a hermeneutic for social and moral transformation in South Africa
\end{abstract}

This article aims to show that the Old Testament concept of the year of jubilee is neither an anachronistic, nor a peripheral detail of Scripture. It is an integral part of it and indeed one hermeneutical tool for interpreting and applying it to social and moral transformation in South Africa.

Israel, liberated from slavery and returning to God, became a paradigm for the liberated slave to return to his inheritance in the year of jubilee celebrated every 50th year. Its underlying concerns are: justice, freedom, human dignity and rights.

Jesus clearly understood his mission in terms of the proclamation of "the year of the Lord's favour" (Luke 4:14-21), and demonstrated this by preaching good news to the poor, freeing the prisoners, restoring sight to the blind, and releasing the oppressed. He linked the mission of his followers with his own and with the promise and gift of the Holy Spirit. Pentecost, seen as fulfilment and announcement of God's promise, demonstrates that the kingdom of God is already here and still to come.

The Book of Revelation gathers together this scriptural theme and presents the jubilee as good news for now and the future. Indeed, God's future is presented as the ultimate jubilee.

Although these institutions cannot be imposed on a secular democracy, there are implications here for holistic evangelism 
and mission as well as for social and moral transformation in South Africa.

These implications, it is argued, should include a reference to the 'missio Dei' as Jesus expressed it: holistic evangelism; a commitment to the values and practices of restorative justice; restoration, healing and hope; economic justice and land reform; ecological responsibility; and moral restoration.

\section{Opsomming}

\section{Die Jubeljaar: ' $n$ hermeneutiek vir sosiale en morele transformasie in Suid-Afrika}

Hierdie artikel is daarop gemik om aan te toon dat die OuTestamentiese konsep van die Jubeljaar nog anachronisties, nog 'n periferiese besonderheid van die Skrif is. In werklikheid is dit 'n integrale deel van die Skrif, en weliswaar 'n hermeneutiese instrument vir die interpretasie en toepassing daarvan vir sosiale en morele transformasie in Suid-Afrika.

Israel, bevry van slawerny en terugkerend na God, het 'n paradigma geword vir die bevryde slaaf om na sy erfenis terug te keer in die Jubeljaar wat elke 50e jaar gevier is. Die onderliggende belange is: geregtigheid, vryheid, menswaardigheid, en regte.

Jesus het sy sending duidelik verstaan in terme van die proklamasie van die "jaar van die Here se guns" (Luk. 4:14-21), en dit gedemonstreer deur goeie nuus aan die armes te verkondig, gevangenes te bevry, blindes se sig te herstel, en die onderdruktes te bevry. Hy het die sendingtaak van sy volgelinge met sy eie verbind met die belofte en gawe van die Heilige Gees. Pinkster, gesien as sowel vervulling en aankondiging van God se belofte, demonstreer dat die koninkryk van God reeds hier is en nog moet kom.

Die Boek van Openbaring vat die Skriftema saam en offer die Jubeljaar as goeie nuus vir die hede en die toekoms. God se toekoms word immers as die finale bevrydingsjaar voorgehou.

Alhoewel hierdie instellings nie op 'n sekulêre demokrasie afgedruk word nie, is hier implikasies vir holistiese evangelisasie en sending asook vir sosiale en morele transformasie in SuidAfrika.

Hierdie implikasies, so word beredeneer, behoort na die 'missio Dei' te verwys, soos dit deur Jesus voorgehou is: holistiese evangelisasie; 'n verbintenis tot die waardes en beoefening van genesende geregtigheid; restourasie, genesing en hoop; ekonomiese regverdigheid en landreformasie; ekologiese verantwoordelikheid; en morele herstel. 


\section{Introduction}

The Spirit of the Lord is on me, because He has anointed me to preach good news to the poor.

He has sent me to proclaim freedom for the prisoners and recovery of sight for the blind, to release the oppressed,

to proclaim the year of the Lord's favour.

With these words, a partial quote from Isaiah 61, Jesus announced his mission in his home town of Nazareth and added: "Today this Scripture is fulfilled in your hearing." (Luke 4:14-21.) In the Gospel according to Matthew 4:17b he announced his mission with these words: "Repent, for the kingdom of heaven is near." In the Gospel according to Mark 1:15 these words announce his mission: "The time has come', he said. 'The kingdom of God is near. Repent and believe the good news!'" In the Gospel according to John, although the term the kingdom of God (John 3:3) is used, Jesus spoke of a time or an hour, which is coming (John 4:21; 5:28; 16:2) "and has now come" (John 5:25a).

The kingdom of God, therefore, was Jesus' central theme. All other themes of teaching, for example repentance, faith, worship, humility, social relations, possessions, and the future, are tied to this theme (Filson, 1977:100-104). This view is also supported by Bornkamm (1974; 1978), Drane (1986), Hunter (1979) and Richardson (1966).

Marshall (2005: 53) identifies in Jesus a twofold strategy:

A prophetic denunciation of the injustices and social evils of the prevailing society on the one hand, and by a calling together of an alternative society to live out the reality of God's kingdom on the other.

Jesus' proclamation of the kingdom of God impinged directly on the major dimensions of social and political life: the use of wealth and power, the exclusion of the weak and disadvantaged from full participation in community, and the use of lethal violence to protect the unjust status quo. Jesus was critical of the injustices of the prevailing social order and called for communal repentance.

He also laid down a new ethic for his followers. In this community, the weak are to be honored, wealth is to be justly distributed, leadership is to take the form of servanthood, and the way of nonviolent peacemaking is to prevail. Seeking to live in accordance with 
the vision of the coming reign of God's justice is to be the supreme concern of its existence (Matt. 6:33; Marshall, 2005:63).

Elsewhere, the New Testament understands the kingdom of God as a dialectic between the already and the not yet, for example in 1 John 3:2:

Dear friends, now we are children of God, and what we will be has not yet been made known. But we know that when He appears, we shall be like Him for we shall see Him as He is.

Therefore, standing in the kingdom that is already here, the followers of Jesus are to anticipate the kingdom that is yet to come in its fullness by praying "your kingdom come, your will be done on earth as it is in heaven" (Matt. 6:10; cf. Luke 11:2b). Indeed, they are to announce or proclaim in word and deed the kingdom that is already here and is still to come!

To return to the partial quote from Isaiah 61 , Jesus clearly understood his mission to inaugurate the kingdom as the announcement or proclamation of "the year of the Lord's favour", that is, of a sabbatical or jubilee year.

The basic presupposition of this article is that the Old Testament concept of the sabbatical and jubilee years are neither anachronistic nor peripheral details of the canon of Scripture, but an integral part of, even a hermeneutical key to interpreting, the whole. This can be demonstrated, not only with reference to the Pentateuch, but also to the perspectives of the historical books of Joshua, Samuel, Kings and Chronicles, Ezra, Nehemiah and Esther. Their purpose is less to provide an exhaustive history than it is didactic in purpose, that is, to interpret the past as a guide for the present and a hope for the future. It can be further demonstrated with reference to Isaiah, Jeremiah, Ezekiel, Daniel, the apocryphal book of 1 Maccabees, and the intertestamental Book of Jubilees. The temptation to separate the historical from the prophetic should be resisted, because faith and spirituality, belief and praxis, the ongoing interaction between God's word and world are always lived out in a certain social, historical context.

Writing in another context, namely that of the history of Martin Luther, Lutheranism and Lutheran spirituality, Hanson (2004:16) writes:

Because we human beings live within the concrete realities of a specific social and historical context, we never approach the 
issues of faith and spiritual practice as an isolated individual with a blank slate. We always navigate in some sort of social boat on a temporal river flowing with various cultural and religious currents.

Prophecy is therefore, never a disembodied word. It is always a word spoken in a specific context, a word that tells forth the heart and mind of God for that context. It is forth-telling rather than foretelling, although it may have both predictive content and consequential warnings if such a word is ignored, resisted or disobeyed (Baker, 1982:975-986). It is also a word capable of being revisited, reapplied and indeed restated in another, later context. It is hoped that this approach to prophecy will avoid later unnecessary discussions about origins, authors and dates, for example about the Pentateuch and the number of Isaiahs responsible for the book known by that name. Thus, the canon of Scripture will be taken as given without further discussion, as this belongs to biblical scholarship of another kind.

Above all, it can be demonstrated in the so-called Nazareth Manifesto where Jesus announced his mission in terms of "the year of the Lord's favour". Jesus' central theme is the kingdom of God, not the jubilee. However, the jubilee is an important hermeneutic in understanding both the nature and implications of the kingdom as a present reality. This can be further supported by the New Testament understanding of Pentecost as both fulfilment and announcement, and in the structure and message of the Book of Revelation. Pentecost announces the already of God's kingdom as "the year of the Lord's favour", whereas Revelation 21:1 sees the appearance of "a new heaven and a new earth" as an eternal jubilee, the fulfilment of Jesus' mission.

This article offers itself, not as an in-depth study, but as an overview and will focus on the sabbatical and jubilee years - and in a somewhat auxiliary capacity, on the cities of refuge - their underlying principles and the ethical implications of those, in the 21st century South African context with a particular focus on social and moral transformation. It will do so by examining the references to these institutions in:

- The Pentateuch, namely in Exodus, Leviticus, Numbers, and Deuteronomy 
- The historical writers and the prophets, namely in the historical writers, Jeremiah, Isaiah, Ezekiel, Daniel, and a post-exilic insight

- The apocryphal book of 1 Maccabees, and the intertestamental Book of Jubilees

- The New Testament, namely in the so-called Nazareth Manifesto, Pentecost, and the Book of Revelation

\section{The Pentateuch}

The Pentateuch contains many important collections or codes of law although translating torah as law "is unsatisfactory because of the narrow definition this calls to mind for most people", writes Birch (1991:171). A better attempt at a translation might be instructions, guidance, the teachings of God and its application, which is much wider than the legal codes themselves.

\subsection{Exodus}

Exodus, focusing on the deliverance of God's people, represents a number of shifts out of something and into something - which is surely the essence of transformation. There are the shifts from servitude to the Pharaoh to the service of Yahweh; from the enforced construction of buildings for the oppressive regime to the willing and joyful construction of the tabernacle for God's presence; and from the domain of the Pharaoh the unmoved mover to Yahweh who enters deeply into Israel's suffering and is moved by it.

Concerning the sabbatical year and the rights of Hebrew slaves, Exodus 21:2, 3 reads:

If you buy a Hebrew servant, he is to serve you for six years.

But in the seventh year, he shall go free without paying anything. If he comes alone, he is to go free alone; but if he has a wife when he comes, she is to go with him. (Exod. 21:4-11 give additional details.)

The Sabbath laws are more than liturgical regulations concerning personal rest, for they are expanded to include rest for the land, animals, Hebrew and foreign slaves, provision for the poor, as well as for wild animals (Exod. 23:11).

Likewise the liturgical practices of the Sabbath day and the three annual feasts are linked with practices of economic justice and ecological responsibility. The significance of rest for the land does 
not lie merely in principles of soil chemistry. Israel is reminded that they do not hold the land in perpetuity but in trust under God, who leases it to them as tenant farmers with both privileges and responsibilities (Lev. 25:23).

This understanding is taken up repeatedly in the parables of Jesus, for example in Matthew 20:1-16; 21:33-46; 25:4-30. The fact that the land does not belong to Israel but to the Lord has obvious, but hardly simple or straight forward, implications for the present and the future of the Middle East - if not for the world!

The attempt to separate liturgy from life, the sacerdotal from the social, would long evoke a prophetic word to God's people, for example that of Isaiah 1:10-17:

I have more than enough of burnt offerings, of rams and the fat of fattened animals; I have no pleasure in the blood of bulls and lambs and goats ... Stop bringing meaningless offerings! ... Stop doing wrong, learn to do right! Seek justice, encourage the oppressed. Defend the cause of the fatherless, plead the case of the widow.

Yet, the liturgical and the sacerdotal are important, for in the regulations regarding the tabernacle, the priesthood and the sacrificial system, Yahweh is seen to be both with and for his people. The tabernacle, writes Fretheim (1996:120):

is a microcosm of creation, the world order as God intended it writ small in Israel, a beginning in God's mission to bring creation to the point where it is perfectly reflective of the divine will. The worship of God at the tabernacle is a world-creating activity, a God given way for the community of faith to participate in God's recreation of a new world, for Israel and for all ... And this community on its way can be assured of the continual glory of the divine presence, which is not finally to be confined to Israel, but is to stream out from there into the larger world.

The dominant narrative themes of Exodus are, therefore, that Israel is God's treasured possession, borne on eagle's wings, and called to be obedient to the covenant; a priestly, holy, and missionary nation to the nations, because the whole earth belongs to the Lord.

\subsection{Leviticus}

Leviticus 25 focuses on the sabbatical year (Lev. 25:1-7), and the year of jubilee (Lev. 25:8-55). It is concerned with the land, domestic and wild animals, the liberation of slaves, the restoration of property, 
and the cancellation of debts. The difference in emphasis concerning the seventh year in Exodus and Leviticus is that the former emphasises the benefits of the institution for the poor.

The jubilee (50th) year was heralded on the Day of Atonement, thus proclaiming a year of atonement or reconciliation, by blowing the ram's horn, the yôhêl from which the institution derives its name. The term jubilee comes from the Latin jubilum, from jubilo, meaning to shout for joy. The blowing of the shôphâr announced three other declarations of freedom: new year's day, the anniversary of the creation of the world (Lev. 23:23-25; Num. 29:1-6); the revelation on Mount Sinai (Exod. 19:13, 16, 19); and the future redemption as announced in Isaiah 27:13:

And on that day a great trumpet will sound. Those who were perishing in Assyria and those who were exiled in Egypt will come and worship on the holy mountain in Jerusalem.

Making both comparisons and contrasts with the Mesopotamian miŠarum (justice), then the Akkadian durârum (liberty), and the proclamation of "freedom" in Egypt, Weinfeld (2000:9) writes that these

... correspond both philologically and substantively to the Israelite institutions of the Sabbatical year and the [yôhêl] (liberation, jubilee). Indeed liberation of slaves, restoration of land to the original owners, and cancellation of debts are among the striking features of 'social reforms', whose aim it is to establish social justice and equality and to assist the weaker members of society. These acts, which are so to speak, the epitome of the establishment of 'righteousness and justice' in Israel.

In Israel these institutions were understood to be divinely ordained "for the Israelites belong to me as servants. They are my servants, whom I brought out of Egypt. I am the LORD your God" (Lev. 25:55).

In sum, the meaning of holiness is focused on distinctiveness and being set apart through relationship with the indwelling God, as well as serving within a mission that is God's but is set deeply within the world for the purpose of its sanctification. (Fretheim, 1996:135.)

The jubilee can be seen as a restoration to an original state. It represented:

- remission of debts; 
- returning to one's own property;

- dealing fairly with respect to buying and selling property (and land);

- providing a time of rest for the land;

- allowing the poor to buy back land sold to reduce poverty (there was a correlation in the people's understanding between land and prosperity, uprootedness and poverty);

- recovery from poverty; and

- manumission for those sold into slavery or indentured labourers.

Provision is made for the redemption of the poor and disenfranchised, as well as for the provision and protection of the poor, aliens, and the release of slaves and their families. The underlying concerns are with justice, freedom, human dignity, and rights. Human dignity and rights are intrinsically related to God's saving acts on behalf of his people, the assertion of divine justice in the face of every human abuse of power and injustice.

\subsection{Numbers}

Numbers makes only a passing reference to the 50th year and no mention of the seventh year. It is nevertheless an important book for this article for at least two reasons: its structure and its reference to the cities of refuge (Num. 35:6-34; cf. Deut. 19 ff.; Josh. 20:1-9).

The reference is in Numbers 36 which is concerned with the inheritance rights of the daughters of Zelophehad - should they marry into other Israelite tribes and their inheritance pass to those tribes in the year of jubilee. Moses ruled that no inheritance in Israel is to pass from tribe to tribe, for each tribe is to keep the land it inherited.

Long thought to be without structure, Numbers can be seen from two angles: the focus on the census (Num. $1 \& 26$ ), and the focus on the journey itself - neither of which are mutually exclusive. The journey narrative is described as both real and symbolic, a journey of faith shaped by God's extraordinary patience, mercy, and determination to fulfil the divine purpose (Ridderbos, 1982:846-848). It is also a journey described in 42 stages: a narrative of transition, the transition from being slaves to being slaves no more, from no sense of identity (except that defined by oppression), to a new sense of identity - that of being God's people. Throughout this transitional journey, Yahweh may be seen as the divine parent and Israel as an 
adolescent child. "Numbers centers on the problems of shaping a community identity in tune with God's intention for the creation." (Fretheim, 1996:137.)

The Book of Revelation picks up on another motif from Numbers. Numbers 33:1-49 mentions 42

... stages in the journey of the Israelites when they came out of Egypt by divisions under the leadership of Moses and Aaron. At the LORD's command Moses recorded the stages in their journey. (Num. 33:1, 2a.)

Revelation 11:15 refers to the sounding of the seventh trumpet, which along with "loud voices in heaven" announces: "The kingdom of the world has become the kingdom of our Lord and of his Christ, and he will reign for ever and ever." In the fourteen verses prior to this, the writer refers to the Gentiles who "will trample on the holy city for 42 months", the two witnesses who "will prophesy for 1260 days" (Rev. 11:2, 3), who will be killed and then raised to life "after ... three and a half days" (Rev. 11:11).

Just as the journey from Egypt to "the plains of Moab ... along the Jordan from Beth Jeshimoth to Abel Shittim" (Num. 33:49) is described in 42 stages, so it can be argued that 42 months, 1260 days. "... a time, times and half a time" (Rev. 12:4), three and a half years and three and a half days are all a shortened way of indicating the period between the already but not yet of God's kingdom, and the appearance of "a new heaven and a new earth", as an eternal jubilee, the fulfilment of Jesus' mission.

The second reason why Numbers is important for this article, is its reference to the cities of refuge mentioned in Numbers 35:6-34. Parallel verses are found in Deuteronomy 19:1-14, and because they are similar with only slight differences, the two references will be examined under the next heading.

\subsection{Deuteronomy}

Deuteronomy 15:1-18 refers to the seventh year as a year for cancelling debts. The seventh year is not a jubilee year, which Deuteronomy does not mention, but contains some of its elements. It is not just about "cancelling debts" (Deut. 15:9b) - a concept possibly taken up by Jesus in the Lord's Prayer (Matt. 6:5-15; Luke 11-13), but about open-handed generosity "towards your brothers and towards the poor and needy in your land" (Deut. 15:11b). Lastly, it is 
also about freeing Hebrew slaves and not only releasing them, but about supplying them liberally.

Numbers 35:6-34 and Deuteronomy 19:1-14 both refer to the cities of refuge, as does Joshua 20:1-9. In Leviticus, provision was made for six towns or cities belonging to the Levites, three on each side of the Jordan, to

... be a place of refuge for Israelites, aliens and any other person living among them, so that anyone who has killed another accidentally can flee there (Lev. 35:15).

This provision did not extend to a murderer, however,

... [a]nyone who kills a person is to be put to death as a murderer only on the testimony of witnesses ... no one is to be put to death on the testimony of only one witness (Lev. 35:30).

Once the assembly had investigated the killing and decided that it was a case of manslaughter or culpable homicide, the perpetrator was to be returned to the city of refuge to which he (or she?) had fled. They were required to remain there until the death of the high priest, who was anointed with the holy oil (Lev. 35:25) - "only after the death of the high priest may he return to his own property" (Lev. 35:28). Any violation of this sanctuary or amnesty could cancel the terms whereby it was granted. No ransom (fine or bribe) was to be accepted "and so allow him to go back and live on his own land before the death of the high priest" (Lev. 35:32).

An earlier reference to the main text in Deuteronomy 19:1-14, is made in Deuteronomy 4:41-43. It reads:

Then Moses set aside three cities east of the Jordan, to which anyone who had killed a person could flee if he had unintentionally killed his neighbour without malice aforethought. He could flee into one of these cities and save his life. The cities are these: Bezer in the desert plateau, for the Reubenites; Ramoth in Gilead, for the Gadites; and Golan in Bashan, for the Manassites.

No conditions for sanctuary or amnesty are given here, except that the provision seems to have operated on a tribal basis. The terms of the amnesty are given in Deuteronomy 19:1-14 and with only slight differences, are similar to those given in Numbers 35:6-34. Reference is made to three cities on the west bank of the Jordan, not yet given by the Lord, and not yet conquered and settled by the invading Israelites. The cities were to be accessible both in terms of their 
location to tribal inheritances and by the construction of "roads to them" (Lev. 19:3). Once again this provision was not offered to one guilty of premeditated murder.

In both Leviticus and Deuteronomy the reasons for this provision for amnesty are similar:

Do not pollute the land where you are. Bloodshed pollutes the land ... Do not defile the land where you live and where I dwell, for I the LORD dwell among the Israelites (Num. 35:33, 34); and

Do this so that innocent blood will not be shed in your land, which the LORD your God is giving you as your inheritance, and so that you will not be guilty of bloodshed. (Deut. 19:10.)

Joshua 20:1-9 repeats the terms and conditions: amnesty or sanctuary did not mean indemnity. Rather, it refered to a relationship of mutual accountability and responsibility between perpetrators, victims (and/or their families), and the community - with terms and conditions. A prototype of restorative justice!

\section{The historical writers and the prophets}

Outside the Torah, what evidence is there of the observance of the sabbatical (seventh) and the jubilee (50th) years in the historical writings and the prophets?

\subsection{The historical writings}

Although there is little notice in the historical writings, there are enough references (even if most of them are negative references, that is, to their neglect or abuse) to show that, in Israel, these institutions were understood to be divinely ordained: "for the Israelites belong to me as servants, whom I brought out of Egypt. I am the LORD your God" (Lev. 25:55). Israel, the servant of Yahweh, liberated from slavery in Egypt and returning to God, becomes the paradigm for the liberated slave to return to his/her inheritance in the sabbatical or jubilee years. Israel, thus liberated by the Lord, is called to behave towards others as God has acted towards them, for this is part of what it means to be holy: "The fiftieth year shall be a jubilee to you ... it is a jubilee and is to be holy for you" (Lev. 25:11a, 12a).

Among the references are: Joshua 20:1-9 (which has already been looked at); 2 Kings 4:1; 2 Chronicles 36:20-23; the narrative sections of Jeremiah $34: 4,5,14-22$ (where the prophet appeals to Deutero- 
nomy, not Leviticus, to the tradition of the seventh rather than that of the 50th year); Ezra 1:1-11 and Nehemiah 5:1-19 and 10:31 give a post-Exilic insight; and 1 Maccabees $6: 49,53$ gives an intertestamental insight.

The historical writings include Joshua, Judges, Ruth, Samuel, Kings, Chronicles, Ezra, Nehemiah and Esther. The writing of history is never simply a chronicle of events, but a reflection on, and an interpretation of those events. It is rarely, if ever, an apolitical or ideology-free reflection and interpretation. Consequently, the Babylonian exile came to be interpreted as God's judgement for the neglect of those institutions meant to embody justice, mercy, and grace - characteristics of both a holy God and a holy people. This is reflected in the closing and the opening verses of 2 Chronicles and Ezra respectively.

A major focus of 2 Chronicles $10-36$ is the history of the southern kingdom of Judah: from the secession of the northern tribes and the establishment of the kingdom of Israel, to the exile and the proclamation of Cyrus, king of Persia. The concluding verses testify to the neglect of the sabbatical year, the consequence of which is linked to God's judgement through Nebuchadnezzar who

... carried into exile in Babylon the remnant, who escaped the sword ... until the kingdom of Persia came to power. The land enjoyed its sabbath rests; all the time of its desolation it rested, until the seventy years were completed in fulfillment of the word of the LORD spoken by Jeremiah. (2 Chron. 36:20, 21; emphasis - SB.)

It is possible that the priestly writer, Ezra, is hinting that the proclamation issued by Cyrus allowing the exiles to return to their inheritance coincided with a probably long, defunct, jubilee year.

Although Israel failed to live graciously in response to God's grace to them Cyrus showed grace to them, and the grace of God embodied in the institutions of the seventh and the 50th years.

The final verses of Chronicles and the opening verses of Ezra make reference to "the word of the Lord spoken by Jeremiah", a word fulfilled in Cyrus' proclamation.

Before asking what that word was, it could be said that the institutions of the sabbatical and jubilee years became a retrospective lens for interpreting the history of God's people - even if that history was a revisionist one! 
Through this lens, an ideological theocracy was envisaged which did not exclude some early form of democratic federalism. Yet, by the time of Saul, there was already evidence of abuse. The objections of Samuel to the movement from a federal theocracy to a monarchy, was that the king was likely to abuse power by appointing a standing army, acquire crown lands, flocks and slaves (1 Sam. 8:4-21a). Later during Saul's reign, threatened by the popularity of David, he addressed his officials in these words:

Listen, men of Benjamin! Will the son of Jesse give all of you fields and vineyards? Will he make all of you commanders of thousands and commanders of hundreds? Is that why you have all conspired against me? (1 Sam. 22:7, 8a.)

Was this, even then, the expected remuneration for state officials/ leading members of the ruling party, in this case Saul's fellow "men of Benjamin"? Was this an ancient equivalent of "the gravy train", albeit it a camel or donkey train?

2 Samuel 9:1-13 records a heart-warming and grace-filled story following the ascendancy of David, the son of Jesse. It is not an explicit reference to either the seventh or the 50th years but embraces - indeed incarnates - the spirit of those institutions. The king seeks, finds, and restores to his inheritance Mephibosheth, the son of Jonathan and grandson of Saul - his enemy. This is an example of return: restoration of inheritance and human dignity, as well as inclusion within the covenant community. For Mephibosheth it was, in effect, a sabbatical or jubilee year - "the year of the LORD's favour" (Is. 61:2a; cf. Luke 4:19).

Sadly, such grace was not always shown to the marginalised, the poor, and the needy. Following the division of the kingdom into Israel and Judah, there is a reference in 2 Kings 4:1-7 of debt leading to child slavery, an economic situation brought about in part by the enclosure movement of the eighth century BCE. This abuse of power resulted in dispossessed agricultural workers, debt, voluntary (and enforced?) slavery. The prophetic rebuke of Isaiah 5:7, 8 probably related to a later development of this.

Both Isaiah and Jeremiah predicted exile and restoration; the latter predicted that the exile would last for 70 years.

\subsection{Jeremiah}

What was "the word of the LORD spoken by Jeremiah" that was fulfilled in "the first year of Cyrus the king of Persia"? 
The quotes made in 2 Chronicles and Ezra are from Jeremiah 25 (cf. Jer. 27:22; 29:10). Jeremiah's prophecy (also quoted in Daniel 9) may here be based on Leviticus 26:32-35, a chapter which follows instructions on the Sabbath and jubilee years (Lev. 25:1-7, 855).

Leviticus 26 refers to rewards for obedience (Lev. 26:1-13), punishments for disobedience (Lev. 26:14-39), and promises to those who turn to God in repentance (Lev. 26:40-46). Among the consequences of disobedience, God promises to lay waste the land, scatter them among the nations, and lie their cities in ruins, so that "the land will enjoy its Sabbath years all the time it lies desolate ... the land will rest and enjoy its Sabbaths ... the rest it did not have during the Sabbaths you lived in it" (Lev. 26:32-35). Yet, to those who "confess their sins and the sins of their fathers - their treachery against me and their hostility towards me" (Lev. 26:40), God promises to remember the covenant and the land, and not to reject, abhor or destroy them: "I am the LORD their God ... I will remember the covenant ... I am the LORD" (Lev. 26:42-45).

The word of the LORD spoken by Jeremiah that was fulfilled in the first year of Cyrus, king of Persia was this:

Therefore the LORD Almighty says this: 'Because you have not listened to my words, I will summon all the peoples of the north and my servant Nebuchadnezzar king of Babylon,' declares the LORD, 'and I will bring them against this land and its inhabitants ... I will completely destroy them and make them an object of horror and scorn, and an everlasting ruin ... This whole country will become a desolate wasteland, and these nations will serve the king of Babylon seventy years.

But when the seventy years are fulfilled I will punish the king of Babylon and his nation, the land of the Babylonians for their guilt,' declares the LORD, 'and I will make it desolate for ever. I will bring upon that land all the things I have spoken against it, all that are written in this book and prophesized by Jeremiah against all the nations. They themselves will be enslaved by many nations and great kings; I will repay them according to their deeds and the work of their hands'. (Jer. 25:8-14.)

In Jeremiah 34 we read that during the siege of Jerusalem by Nebuchadnezzar, king of Babylon, Zedekiah, the last king of Judah, had made a solemn covenant with all the people in Jerusalem to proclaim freedom for their slaves. As a result of this act, whether of grace or necessity, Jeremiah made a gracious promise to the king in 
the name of the Lord: he would not die by the sword, but peacefully. Afterwards, when the besieging army withdrew, this collective act was reversed. As a result Jeremiah spoke a word of judgement in the name of Yahweh: Zedekiah would go into exile.

Confident in this proclamation of return, restoration and freedom, Jeremiah, while still a prisoner of Zedekiah, had made an investment for the future. This gave the besieged city a sign of hope: just as God's words of judgement were about to come true, so too would God's words of grace and promise. He bought a field at Anathoth from his cousin Hanamel (Jer. 32:9). In the midst of treachery and judgement, the word of God came to Jeremiah as a word of promise and hope:

I will bring health and healing ... I will heal my people and will let them enjoy abundant peace and security. I will bring Judah and Israel back from captivity and will rebuild them as they were before. I will cleanse them ... and will forgive them all their sins of rebellion against me (Jer. 33:6-8).

Beyond that, Jeremiah spoke of a greater promise and hope: the coming of a righteous branch from David's line who would act justly and give peace and security.

\subsection{Isaiah}

Isaiah 61 refers to the proclamation of "the year of the LORD's favour and the day of vengeance of our God" (Isa. 61:2b). This is understood in terms of justice, judgement and redemption as "good news to the poor, binding 'up the broken-hearted', proclaiming freedom for the captives and release ... for the prisoners" (Isa. 61:1), comfort and provision, rebuilding and restoration, holiness (always God's primary concern for his people), and witness to the goyim. The nations already are seen to have a future share in the blessings of the covenant (Ackroyd, 1980:368).

The purpose of this proclamation was to bring about equality and social rights. It became a model for the redemption of the soul, the forgiveness of sin on Yom Kippur. In the Qumran scrolls it serves as a model for the redemption of the collective and the erasure of sins at the End of Days. According to the calculation of the pešer of Qumran, this corresponds to the end of the tenth jubilee cycle.

Such an exegesis of Isaiah 61:1-3 must have lain in the background of Luke 4:16-19, in which Jesus sees himself as bearing to the reader news of freedom and a year of grace from the Lord. The pro- 
phecy of Isaiah $61: 1-3$, whose source is connected with the jubilee of years which passed between the destruction of the temple (586 $B C E)$ and the declaration of Cyrus (536 BCE), acquire mythicalapocalyptic significance during the period of the Second Temple being motivated by calculations of the end of 70 sabbatical years (Daniel) and the jubilees (Midrash Melchisedek). It thus became a focus for the longing for redemption in both Judaism and Christianity (Weinfeld, 2000:211).

Isaiah also linked the jubilee with the coming of the Spirit, a theme taken up by Luke (and other New Testament writers) in his account of Jesus' baptism, anointing, temptation, and proclamation of "the year of the Lord's favour" (Luke 4:19), but not yet "the day of vengeance of our God" (Is. 61:2b). Luke again takes up this notion of an extended period of grace before the coming judgement in Acts 2:1441.

Following the infilling with the Holy Spirit, Peter attempts to explain this phenomenon to the pilgrims at Pentecost by quoting the prophet Joel 2:28-32. Pentecost is clearly a sign that the last days have appeared, though the signs of "blood and fire and billows of smoke", the sun being turned "to darkness and the moon to blood before the coming of the great and glorious day of the Lord" (Acts 2:17a, 19b, 20), have not yet been given. For now, the promise of the forgiveness of sins and "the gift of the Holy Spirit" is "for all whom the Lord our God will call" (Acts 2:38, 39).

\subsection{Ezekiel}

Ezekiel 7 (especially verses 10-14), may be a reference to a revival of the institution of the seventh or 50th year in a fruitless attempt to prevent the inevitable judgement: "Though they blow the trumpet and get ready, no one will go into battle, for my wrath is upon the whole crowd" (Ezek. 7:14). The closing chapters, namely 36, 37, 4048 give expression to the vision of restoration: a rebuilt temple, which is the centre of a holy nation, priesthood, prince and people, from which grace flows, not only to, but from Israel. In Ezekiel 47, the prophet sees life-giving water flowing from the temple, bringing life, fruitfulness and healing (Ellison, 1982a \& 1982b).

In Revelation $22: 2 b$, this reference is extended as a promise for "healing of the nations". Ezekiel 46:16-18 refers to the prince and "the year of freedom" (v. 17): 
The prince must not take any of the inheritance of the people, driving them off their property. He is to give his sons their inheritance out of his own property, so that none of my people will be separated from his property. (Ezek. 46:18.)

Just as Yahweh will again show Himself gracious by restoring his people to their God-given inheritance, so God requires his people to show grace.

Ezekiel's symbolism was deeply rooted in his priestly heritage, but he was no narrow ritualist. Rather, his message was shaped by a strong eschatological vision - that of a holy God dwelling among a holy people: "And the name of the city from that time on will be: THE LORD IS THERE." (Ezek. 48:35.)

Again in Revelation this is extended in the vision of "a new heaven and a new earth ... the Holy City, the new Jerusalem, coming down out of heaven from God", the place of God's throne, God's dwelling, from which the water of life will flow, bring fruitfulness, and

... the healing of the nations ... The throne of God and of the Lamb will be in the city, and his servants will serve him. They will see his face, and his name will be on their foreheads ... and they will reign for ever and ever (Rev. 21:1-22:6).

In this vision "they" extend beyond the people of Israel to include people "from every tribe and language and people and nation", whom God has made "to be a kingdom and priests to serve ... God, and they will reign on the earth" (Rev. 5:9b, 10).

\subsection{Daniel}

Daniel 9 is another passage which refers "to the word of the LORD given to Jeremiah the prophet that the desolation of Jerusalem would last seventy years". The prophecy of Jeremiah moved Daniel to repentance and intercession on behalf of his people for the fulfilment of that word. Consequently, the concept of the jubilee was reinterpreted in the midst of national judgement as a promise of hope and restoration.

Like Ezekiel, there is a strong, eschatological hope expressed in these writings, with the final chapter looking beyond history to its consummation, with an illusion to the future resurrection of the dead.

Multitudes who sleep in the dust of the earth will awake: some to everlasting life, others to shame and everlasting contempt. Those who are wise will shine like the brightness of the 
heavens, and those who lead many to righteousness, like the stars for ever and ever. (Dan. 12:2, 3.)

Thus the eschatological hope is expressed, not only in terms of justice and mercy for God's people, but of God's people active in mission.

Daniel 9 speaks challengingly to God's people, anytime and anywhere, of the correlation between God's purposes, promises, and prayer. It is while Daniel is still in prayer and repentance that he receives an angelic vision assuring him that his prayer has been heard. This vision looks beyond the imminent deliverance to another, a future, indeed even the ultimate deliverance of God's covenant people.

Thus, the Book of Daniel also understands God's judgement with reference to the seventh or 50th years of grace. Judgement is in part due to the abuse or neglect of these institutions. Restoration is seen as the proclamation of a jubilee, a multiple of seven sabbatical years, culminating in a 50th year of jubilee.

The references to various periods of sevens, whether 7 "sevens", and 62 "sevens"' - after which "the Anointed One will be cut off ... the city and the sanctuary" destroyed, and "a covenant with many for one" "seven" confirmed, in the middle of which "an abomination that causes desolation" (Dan. 9:24-27), an event which Jesus saw as being in the future (cf. Matt. 24:15) - are fascinating sources for students of apocalyptical literature. They need not detain us here, other than to suggest that the anticipation of the Anointed One, or Messiah, is seen in terms of the ultimate jubilee of jubilees. But that is still to come - and to come!

So judgement, mercy, exile, restoration, redemption in the present, and ultimately in the future - or, the ultimate redemption - are seen in terms of a jubilee (Young, 1970:698-700).

\subsection{A post-exilic insight}

Sadly, the return from exile did not conclude transgression, put an end to sin, or "bring in everlasting righteousness" (Dan. 9:24a). In Nehemiah 5:1-19 we read that even during the rebuilding of the city there was a return to abuse. This abuse resulted in many mortgaging their fields, vineyards and homes; and indeed, selling their sons and daughters into slavery. 
Nehemiah's response was to call an assembly with instructions to "walk in the fear of our God" and to stop the practice of usury.

Give back to them immediately their fields, vineyards and olive groves and houses, and also the usury you are charging them the hundredth part of the money, grain, new wine and oil.

Later, a national day of fasting, confession and prayer was held, and this resulted in the renewal of the covenant: "a binding agreement" (Neh. 9:38) was made, part of which included the pledge: "Every seventh year we will forgo working the land and will cancel all debts" (Neh. 10:31).

The advantages of this institution were manifold. It would

- prevent the accumulation of land on the part of the few to the detriment of the community at large;

- render it impossible for anyone to be born in absolute poverty since everyone had his/her hereditary access to the land;

- preclude those inequalities which are produced by extremes of wealth and poverty, and which result in one being dominant over the other;

- utterly do away with slavery;

- afford a fresh opportunity to those who were reduced by adverse circumstances to begin again their industry in the patrimony which they had forfeited; and

- periodically rectify the disorders which creep into the state in the course of time, precluding the division of the people into nobles and plebeians (into classes locked in a Marxian political struggle) - and preserve the theocracy inviolate.

At least that was the intention, the ideal; the reality though was and will remain different. Thus the jubilee would remain a symbol of hope - that one day the ideal would be the real. During the intertestamental period, this hope would take on new expectations and new shapes.

\section{The apocryphal book of 1 Maccabees, and the intertestamental Book of Jubilees}

1 Maccabees 6:48-54 tells of the capture of Bethzur and the siege of Mount Zion by the Syrians. King Antiochus V "granted peace terms 
to the people of Bethzur, who evacuated the town; it lacked store of provisions to withstand a siege, since the land was enjoying a sabbatical year". Likewise, those defending the sanctuary at Jerusalem "had no stocks of provisions, because it was the seventh year, and those who had taken refuge in Judaea from the pagans had eaten up the last of their reserves. Only a few men were left in the Holy Place, owing to the severity of the famine; the rest had dispersed and gone home."

Another intertestamental Jewish work is the Book of Jubilees "extant completely only in Ethiopic and partly in Latin, though fragments in the original Hebrew have now been found at Qumran". This work

$\ldots$ is a midrash or legendary rewriting of Genesis and the early chapters of Exodus. It gives the biblical history a detailed chronology, calculated in jubilee periods of 49 years, each divided into 7 weeks of years, each year a solar year of 364 days. The revelation at Sinai occurs in the 50th jubilee since the Creation. (Several texts from Qumran employ jubilee periods in historical and eschatological speculation.) (Brauckham, 1982:625, 626.)

Jubilees was probably written in the late second century BCE in (proto-) Essene circles, shortly before the Qumran sect came into existence. It was popular at Qumran, where its special legal precepts and calendar were observed. (It is cited by name in CD 16.13f; Brauckham, 1982:626). It was written against the background of hellenising influences, and in opposition to them. Its author (probably Pharisaic) glorifies the torah as distinguishing Israel from the goyim.

Whether the Qumran influenced Jesus or not, it could be said that by his time the idea of the jubilee had become somewhat exclusive, determining who was in, and who was out. Jesus would give it a new, radical, and universal interpretation and application: that of Israel's mission to the goyim.

\section{The New Testament}

The New Testament will be examined from three perspectives, namely the so-called Nazareth Manifesto; Pentecost; and the Book of Revelation.

\section{1 The so-called Nazareth Manifesto}

And so 
Jesus full of the Holy Spirit, returned from the Jordan and was led by the Spirit in the desert, where for forty days he was tempted ... [He] returned to Galilee in the power of the Spirit, and ... taught in their synagogues, and everyone praised him. He went to Nazareth ... and on the Sabbath day he went into the synagogue, as was his custom. And he stood up to read ... the prophet Isaiah ... Then he rolled up the scroll ... sat down $\ldots$ and he said to them, 'Today this scripture is fulfilled in your hearing' (Luke 4:1, 2a, 14-17, 20, 21).

"Today this scripture is fulfilled in your hearing" - this was Jesus' one line commentary on a partial quote from Isaiah 61 . Thus $\mathrm{He}$ proclaimed his mission in terms of "the year of the Lord's favour", a jubilee year.

Isaiah linked the jubilee year with the anointing of the Spirit. Luke presents Jesus anointed by the Spirit, called the Beloved (Is. 3:21, 22), full of the Spirit, led by the Spirit and "in the power of the Spirit" as the One who inaugurates God's kingdom as "the year of the LORD's favour", but not yet "the day of vengeance of our God" (Is. $61: 2 b)$.

The 'voice from heaven' should be understood against the background of intertestamental Judaism. This period gives a threefold perspective of the activity of the Spirit: (a) during Judaism the Holy Spirit was the spirit of prophecy; (b) this prophetic gift had been stilled with the last Old Testament writings; (c) this activity of the Holy Spirit was to be restored at the start of the Messianic era. The descent of the Holy Spirit and the voice from heaven attest that, with Jesus, God restored the broken communication between himself and Israel. (De Smidt, 1997:148.)

The coming of the Spirit at the Jordan can also be seen as an inauguratory stage in God's design. It is the marking of the beginning of the fulfilment of the hope of a new age enunciated in Isaiah 61:1-2. The Spirit has a unique eschatological significance because Jesus' ministry, commissioned at the Jordan, brought the eschatological kingdom into the present. The Jordan event represents the inauguration of Jesus' messianic task. (De Smidt, 1997:148.)

Put more simply: "Today this scripture is fulfilled in your hearing" proclaimed a jubilee year - indeed the jubilee year!

Peterson $(1991: 96,97)$ states: 
Stobel argues that AD 26-27 was a jubilee year, and that Jesus' citation of the Isaiah text took account of this actual jubilee year, when the trumpets were sounding throughout the land and the Levitical liberation traditions were remembered again.

Thus by unrolling and rolling up, by opening and closing the scroll, "Jesus unsealed the scroll by revealing its present meaning, his inaugurating leadership in the kingdom of God, the good news." (Peterson, 1991:64). "'The time has come,' he said. 'The kingdom of God is near. Repent and believe the good news!'" (Mark 1:15.) In the synagogue at Nazareth, Jesus adds the kairos word, "Today" (Luke 4:2a), thereby giving it a sense of urgency.

The urgency is in the attending, being wholly present to the presence of God that Christ presents to us in his coming. Thorleif Boman in his profound study of time in the Bible, says, "Present means exactly what the word says; 'presence', i.e., we are at the place where action is taking place" ... [the] emphasis is never on the future as such, but on the present that is pregnant with futurity ... [the New Testament] uses two words for time, chronos and kairos. Chronos is duration, kairos is opportunity. We coolly measure chronos with clocks and calendars; we passionately lose ourselves in kairos by falling in love or leaping into faith. We must never ... dismiss chronos as inferior or unimportant ... But only by means of kairos can we comprehend and participate in Christ's coming. For the coming of Christ cannot be confined to a date - it is primarily a meeting, an arrival which is already in process of taking place, although not yet consummated. (Peterson, 1991:192.)

This kingdom, still to come in its fullness, but already breaking in upon us, Jesus proclaimed at Nazareth. All four Gospels testify to the presence of the kingdom in the preaching of good news to the poor, freedom for the prisoners, recovery of sight for the blind, and release for the oppressed. Repeatedly Jesus is shown to have authority to forgive, to heal and to call men and women into the kingdom; He is seen to have authority over nature, including sickness and death, and the supernatural - all the forces that oppress, blind, imprison and impoverish humanity.

Not long into his ministry, Jesus' kinsman John the Baptist was imprisoned, because of his opposition to the Herodian regime. In a crisis of faith he sent a message to Jesus asking: "Are you the one who was to come, or should we expect someone else?" (Matt. 11:16.)

Jesus' answer is revealing (and cryptic). 
Go back and report to John what you hear and see: The blind receive sight, the lame walk, those who have leprosy are cured, the deaf hear, the dead are raised, and the good news is preached to the poor. Blessed is the man who does not fall away on account of me. (Matt. 11:4-6.)

In effect, Jesus is saying go and tell John that the jubilee is being proclaimed in word and deed. For John, both the irony of this and the trial of his faith, was that he was in prison. This was another sign that the kingdom is already here, but not yet fully here, and that for him, freedom and release would come in death.

It cannot be without significance that Jesus rolled up the scroll and handed it back to the synagogue attendant in the middle of Isaiah 61:2 as we have it. The prophet spoke of the anointing of the Spirit of the Sovereign Lord "to proclaim the year of the LORD's favour and the day of vengeance of our God". The Nazareth Manifesto announces the year of the Lord's favour, but not yet the day of vengeance of our God.

Elsewhere, and in other words, Jesus would rebuke the vengeful intention of James and John, who wanted to call down judgement on a Samaritan village for their refusal to welcome him: "the Son of Man did not come to destroy men's lives, but to save them" (Luke 9:56). Again: "God did not send his Son into the world to condemn the world, but to save the world through Him." (John 3:17.)

This is not to say that future - or for that matter, present - judgement is not entrusted to Jesus, but rather that his primary mission is to bind up, to proclaim freedom and release, to comfort, restore and heal, all that is embraced by the word shalom, all that is promised in the notion of salvation.

"God did not send his Son into the world to condemn the world, but to save the world through Him." With similar words the writer of the fourth Gospel begins to conclude his narrative: "As You sent Me into the world", Jesus prays to the Father (John 17:18) on the eve of his death, "I have sent them into the world". Later, on the evening of his resurrection, Jesus comes to his disciples with the words: "Peace be with you! As the Father sent Me, I am sending you." And with that He breathed on them and said, "Receive the Holy Spirit. If you forgive anyone his [or her] sins, they are forgiven; if you do not forgive them, they are not forgiven." (John 20:21-23.)

Just as Jesus' mission to inaugurate the kingdom of God is linked with the Holy Spirit, so He links his followers' mission in the world 
with the Holy Spirit. In both Luke's Gospel and his follow-up account in Acts, their worldwide mission to proclaim the jubilee is dependent on the empowering of the Spirit of mission:

... repentance and forgiveness of sins will be preached in [my] name to all the nations, beginning in Jerusalem. You are witnesses of these things. I am going to send you what the Father has promised; but stay in the city until you have been clothed with power from on high. (Luke 24:47-49.)

And later:

Do not leave Jerusalem, but wait for the gift my Father promised ... in a few days you will be baptized with the Holy Spirit ... you will receive power when the Holy Spirit comes on you; and you will be my witnesses in Jerusalem, and in all Judea and Samaria, and to the ends of the earth (Acts 1:4b, 5b, 8).

That the jubilee is not a peripheral idea in Scripture, but an integral part of it, indeed one hermeneutical key to interpreting the whole, is supported not just in the so-called Nazareth Manifesto (where Jesus announced his mission), but in Pentecost, where the church announced its mission to the world.

\subsection{Pentecost - fulfilment and announcement}

In the New Testament there are three references to Pentecost, namely Acts $2: 1 ; 20: 16$ and 1 Corinthians 16:8.

Pentecost - or rather pentêkonta hêmeras - is how the Septuagint (LXX) translates the Hebrew $h^{a}$ miššim yôm, "fifty days" of Leviticus 23:15. The "fifty days", or seven weeks was called châg shebûâh, "Feast of weeks" (Exod. 34:22; Deut. 16:10). Its observation is indicated in the days of Solomon (2 Chron. 8:13) as the second of the three annual festivals, namely unleavened bread, weeks and tabernacles. The liturgical feast also had social implications.

Pentecost was a time of joy and gratitude for the blessings of the harvest. Jeremiah spoke to a rebellious people, whose wrongdoings had deprived them of those blessings, a people who did not "fear the LORD our God, who gives autumn and spring rains in season, who assures us of the regular weeks of harvest" (Jer. 5:24).

In the intertestamental period and later, Pentecost was regarded as the anniversary of the giving of the torah at Sinai "(Jubilees 1:1 with 
6:17; TB, Pesahim 68b; Midrash, Tanhuma 26c)" (Freeman, 1982: 909).

Pentecost is, therefore, both the fulfilment of God's promise that the Spirit would be poured out "on all people" (Joel 2:28a; Acts 2:17a), and the announcement that, "Today" that promise still stands, awaiting fulfilment.

Repent and be baptized ... in the name of Jesus Christ for the forgiveness of your sins. And you will receive the gift of the Holy Spirit. The promise is for you and your children and for all who are far off - for all whom the Lord our God will call. (Acts 2:38, 39.)

It is, therefore, possible to see the church age, "the last days" of Joel $2: 28 a$ and Acts 2:17a, as the announcement of "the year of the Lord's favour" (Luke 4:19b), that is, of a sabbatical or jubilee year. Pentecost announces the already of God's kingdom, whereas Revelation (21:1) sees the appearance of "a new heaven and a new earth" as an eternal jubilee, the fulfilment of Jesus' mission.

Now the dwelling of God is with men [and women], and he will live with them. They will be his people, and God himself will be with them and be their God. He will wipe every tear from their eyes. There will be no more death or mourning or crying or pain, for the old order of things has passed away. (Rev. 21:3b, 4.)

\subsection{The Book of Revelation, a summing up and a presentation - an ending and a beginning}

Without doubt, the Book of Revelation has produced commentators and commentaries more weird and wonderful than some of its imagery (Kümmel, 1984:462-466; Morris, 1982:1027-1029). It may, therefore, be helpful to heed the words of Wilcock and Peterson.

Wilcock (1989:181-2) writes:

Revelation should not stand on its own as an independent framework, but should be taken as a repetition in highly coloured language of the sequence already made sufficiently clear in the non-symbolic teaching of the Gospels and Letters.

Peterson (1991:xi-xii) writes:

I do not read the Revelation to get additional information about the life of faith in Christ. I have read it all before in law and 
prophet, in gospel and epistle. Everything in the Revelation can be found in the precious sixty-five books of the Bible. The truth of the gospel is already complete, revealed in Jesus Christ. There is nothing new to say on the subject. But there is a new way to say it. I read the Revelation not to get more information but to revive my imagination.

Wilcock identifies a literary structure which may also be a helpful hermeneutical key to "unlocking" its "Essential Vision, The Message of Revelation". He sees Revelation as consisting of seven scenes, each consisting of seven subdivisions, plus an eighth scene, also consisting of seven subdivisions.

This gives a literary structure represented by the following equation: $7 \times 7=49+1=50$. If seven is the number of completeness, and 7 sevens the number of complete completeness, "why is there an eighth Scene?" asks Wilcock (1989:202).

Seven is the number of completeness, for example "the week of six working days is crowned with a sabbath of rest ... a pattern established by God himself in his work of creation (Gen. 1:1-2:3). But it is also ... ratified ... in his work of redemption. It is on Good Friday, the sixth day of the week that the redeeming work of Christ reaches its climax ... and the Saturday is the day of rest, the seventh day, which crowns the week of that mighty labour of love" (Wilcock, 1989:202). The seventh day proclaimed the end of the law and the entire Old Testament system based upon it.

"But the Sunday, the eighth day, did more. It proclaimed Christ to be 'Son of God in power ... by his resurrection from the dead' (Rom. 1:4). The first day of a new week was in fact the first day of a new age. Small wonder then, that the pattern laid down in creation and amplified in redemption should appear in the last chapters of the Bible" (Wilcock, 1989:202), which see the kingdom inaugurated in Christ, now consummated in Christ: "The kingdom of the world has become the kingdom of our Lord and of his Christ, and He will reign for ever and ever." (Rev. 11:15b.)

Scripture goes even further in providing blueprints to explain the last Scene of Revelation. For up to $21: 8$ we have had not only seven Scenes, but seven Scenes with seven sections each forty-nine visions. And no Jew could doubt for a moment the significance of 'forty-nine', and what should follow it. 'You shall count seven weeks of years, seven times seven years, so that the time of the seven weeks of years shall be to you forty-nine years. Then you shall sound abroad a loud trumpet ... And you 
shall hallow the fiftieth year, and proclaim liberty throughout the land to all its inhabitants; it shall be a jubilee for you' (Lv. 25:8$10)$. With the year of jubilee comes the release of every slave, the reunion of every family, the restitution of all wrongs. The eighth which follows the seven, and the fiftieth which follows the seven times seven, are alike symbolic of a glorious new beginning. (Wilcock, 1989:202, 203.)

Revelation, the 66th book of the Bible, gathers together a theme which runs through the Pentateuch, the historical writings and the prophets (as well as some intertestamental writings): Jesus' understanding of his mission, the notion of Pentecost as fulfilment and promise, and the New Testament vision of the kingdom of God as already, but not yet fully here. And announces it as a year of jubilee, both for now and the future.

\section{Conclusion}

Thus, it can be said that the Old Testament concept of the sabbatical and jubilee years are neither anachronistic nor peripheral details of the canon of Scripture. Rather, they are an integral part of, and indeed one of the hermeneutical keys to interpreting, the whole. Further, it could be said to be a vital dynamic in the church's understanding and praxis of evangelism and mission as well as a hermeneutic for social and moral transformation in South Africa.

Obviously these institutions - which even in ancient Israel may have been more ideal than real, more intentional than functional - cannot be imposed on a secular, constitutional, democracy that makes no claim to be God's covenant people in any biblical sense of that term. Nevertheless, there are implications here for holistic evangelism and mission in South Africa that not only transcend, but can transform culture, politics, and economics.

What these implications are is surely material for further academic research. An Internet search has revealed very little recent (post2000) academic writing, and no evidence that black theologians have written on this topic; considered here as of fundamental importance in postapartheid democratic South Africa. The intention of this article is to promote and encourage that debate in the South African context. Whatever answers may emerge from such research, would need to include a strong reference to the biblical and gospel principles of the missio Dei, expressed by Jesus in the Nazareth Manifesto as: 
- holistic evangelism - preaching Good News to the whole person;

- a commitment to the values and practices of restorative justice - binding up the wounds of crime by proclaiming justice, forgiveness, reconciliation, and freedom for victims and offenders of crime, their families, and communities;

- restoration, healing, and hope - proclaiming recovery of sight for the blind, figuratively speaking, in order that South Africa can engage the future with a realistic vision of hope thus facilitating a more just and hopeful future;

- economic justice, productivity, land reform, and nation building - releasing the oppressed; especially by demonstrating this cultural commission;

- ecological responsibility - caring for God's creation; and

- moral restoration - proclaiming and living kingdom values whereby the church takes ownership and initiative for this responsibility which is shared by all South Africans.

These call for both the development of a specific spirituality and practical, measurable initiatives and programmes.

In a previous article (Barry, 2009:1-36), I outlined some practical and measurable responses that the Christian community could make in response to the question: How?

These included identifying and utilising the church's resources in terms of the church's:

- prophetic ministry,

- evangelical ministry,

- pastoral ministry,

- teaching ministry,

- liturgical and sacramental life,

- ministry of presence,

- healing ministry,

- people, and

- commitment to social justice. 
Kenneth Leech reminds the church that the jubilee as a symbolic frame for theological work

... remains vital with its fourfold stress on setting free the oppressed, the cancelling of debts, the restoration of the land, and the pursuit of all this in a spirit of festivity, symbolized by the blowing of trumpets. It is possible that Jubilee 'may contain the spark that can ignite spiritual fires capable of bringing about the personal, ecclesial and social transformation that today's world so urgently needs'. (Leech, 2001:229.)

\section{List of references}

ACKROYD, P.R. 1980. The Book of Isaiah. (In Laymon, C.M., ed. The interpreter's one-volume commentary on the Bible. Nashville: Abingdon. p. 368.)

BAKER, J.P. 1982. Prophecy, prophets. (In Douglas, J.D., ed. New Bible Dictionary. Leicester: InterVarsity. p. 975-986.)

BARRY, S. 2009 Taking responsibility for reconciliation: a Christian response to the legacy and challenges of the South African Truth and Reconciliation Commission (TRC). In die Skriflig, 42(2):1-36.

BIRCH, B.C. 1991. Let justice roll down: the Old Testament, ethics, and Christian life. Louisville: John Knox.

BORNKAMM, G. 1974. The New Testament: a guide to its writings. London: SPCIC.

BORNKAMM, G. 1978. Jesus of Nazareth. London: Hodder \& Stoughton.

BRAUCKHAM, R.J. 1982. Book of Jubilees. (In Douglas, J.D., ed. New Bible Dictionary. Leicester: InterVarsity. p. 625-626.)

DE SMIDT, J.C. 1997. Possessed by the Spirit: Jesus in the pentecostal tradition. (In Du Toit, C.W., ed. Images of Jesus. Pretoria: UNISA. p. 141161.)

DRANE, J.W. 1986. Introducing the New Testament. Tring: Lion.

ELLISON, H.L. 1982a. Book of Ezekiel. (In Douglas, J.D., ed. New Bible Dictionary. Leicester: InterVarsity. p. 363-364.)

ELLISON, H.L.1982b. Ezekiel. (In Douglas, J.D., ed. New Bible Dictionary. Leicester: InterVarsity. p. 363-363.)

FILSON, F.V. 1977. A New Testament history. London: SCM.

FREEMAN, D.F. 1982. Feast of pentecost. (In Douglas, J.D., ed. New Bible Dictionary. Leicester: InterVarsity. p. 909.)

FRETHEIM, T.E. 1996. The pentateuch. Nashville: Abingdon.

HANSON, B. 2004. Grace that frees: the Lutheran tradition. (In Sheldrake, P., ed. The traditions of Christian spirituality series. London: Darton, Longman \& Todd. p. 16.)

HOLY BIBLE. 1999. New international version. Cape Town: Bible Society of South Africa.

HUNTER, A.M. 1979. The work and words of Jesus. London: SCM.

KÜMMEL, W.G. 1984. Introduction to the New Testament. London: SCM.

LEECH, K. 2001. Though our long exile: contextual theology and the urban experience. London: Darton, Longman \& Todd. 
MARSHALL, C. 2005. The little book of biblical justice: a fresh approach to the Bible's teachings on justice. Intercourse: Good Books.

MORRIS, L. 1982. Book of Revelation. (In Douglas, J.D., ed. New Bible Dictionary. Leicester: InterVarsity. p. 1027-1029.)

PETERSON, E.H. 1991. Reversed thunder: the Revelation of John and the praying imagination. San Francisco: Collins.

RICHARDSON, A. 1966. An introduction to the theology of the New Testament. London: SCM.

RIDDERBOS, N.H. 1982. Book of Numbers. (In Douglas, J.D., ed. New Bible Dictionary. Leicester: InterVarsity. p. 846-848.)

WEINFELD, M. 2000. Social justice in ancient Israel and in the ancient near East. Jerusalem: HU Magnes.

WILCOCK, M. 1989. Essential vision: the message of Revelation. (In Motyer, J.A. \& Stott, J.R.W., eds. The Bible speaks today series. Leicester: InterVarsity. p. 202-203.)

YOUNG, E.J. 1970. Daniel. (In Guthrie, D., Motyer, J.A., Stibbs, A.M. \& Wiseman, D.J., eds. The New Bible Commentary revised. London: InterVarsity. p. 698-700.)

Key concepts:

Jubilee, year of

redemption

restoration

transformation

Kernbegrippe:

Jubeljaar

restourasie

transformasie

verlossing 
